\title{
Everything is Conceivable: A Note on an Unused Axiom in Spinoza's Ethics
}

\author{
Justin Vlasits \\ University of Illinois at Chicago \\ jvlasits@uic.edu
}

\begin{abstract}
Spinoza's Ethics self-consciously follows the example of Euclid and other geometers in its use of axioms and definitions as the basis for derivations of hundreds of propositions of philosophical significance. The choices about what to define and what to leave as an undemonstrated axiom are clearly essential in such a project and were made by Spinoza with great care. Usually, when coming up with first principles in this sort of system, one aspires to have a list of axioms and definitions, each of which is necessary for at least one of the theorems to be proven. Spinoza's Ethics fails in this regard with EIa2. In this brief note, I show how Spinoza intended to and should have appealed to this axiom in his proof of EIp4 by appealing to parallels between the first four propositions of the Ethics and the correspondence with Henry Oldenburg.
\end{abstract}

Keywords: Spinoza, PSR, Axiomatics, Geometrical Method

Spinoza's Ethica ordine geometrico demonstrata self-consciously follows the example of Euclid and other geometers in its use of axioms and definitions as the basis for derivations of hundreds of propositions of philosophical significance. The choices about what to define and what to leave as an undemonstrated axiom are clearly essential in such a project and were made by Spinoza with great care. Usually, when coming up with first principles in this sort of system, one aspires to have a list of axioms and definitions, each of which is necessary for at least one of the theorems to be proven.

There are certainly definitions in Euclid that fail in this regard-a large number of definitions of basic mathematical entities such as "number" or "point" are never mentioned in any proofs. This fact has naturally raised scholarly concerns about their purpose and Euclid's logical acumen. ${ }^{1}$ If we look at Spinoza's attempt at the Euclidean program, we notice that he is much more rigorous in this regard, with very few exceptions. ${ }^{2}$ The second axiom listed in the work reads:

EIa2: What cannot be conceived through another, must be conceived through itself. ${ }^{3}$

Id, quod per aliud non potest concipi, per se concipi debet. ${ }^{4}$

\footnotetext{
${ }^{1}$ Most modern scholars no longer hold that this fact points to any failure on Euclid's part, but here is not the place to discuss it. I refer interested readers to Mueller, "Euclid's Elements"; Mueller, Philosophy of Mathematics (esp. 38-40); Mueller, "Mathematical Starting Point"; Netz, "Shaping of Deduction" (90-103). The idea that axioms are introduced whenever they are needed is also a feature of 17 th century texts, such as Lamy, Les Éléments. On 17 th century treatments of axioms in geometry, see Kokomoor, "Seventeenth Century Geometry" (285 ff).

2 Axiom 2 of the Short Physical Digression that follows EIIp13s is also never explicitly cited.

3 Translations are from Curley, Collected Works of Spinoza.

${ }^{4}$ The Latin text used is that of Gebhardt, Spinoza Opera.
} 
Spinoza never explicitly appeals to this axiom in the Ethics. The aim of this note is to explain how this axiom came into Spinoza's text and argue that it indeed should have been referenced in the proof of a central proposition:

EIp4: Two or more distinct things are distinguished from one another, either by a difference in the attributes of the substances or by a difference in their affections.

Duae aut plures res distinctae vel inter se distinguuntur ex diversitate attributorum substantiarum, vel ex diversitate earundem affectionum.

Both EIa2 and EIp4 are rightly considered essential parts of Spinoza's system, ${ }^{5}$ so understanding their relationship promises to shed light on Spinoza's thought generally.

There has been, so far as I know, only one previous attempt to locate this axiom in a particular place in the text of the Ethics, that of Proietti, "Un assioma inutile in Spinoza", whose solution is endorsed by Mignini, Spinoza Opere (1630). On this interpretation, EIa2 must be used in the proof of EIp10, which I quote here in full:

EIp10: Each attribute of a substance must be conceived through itself.

Dem.: For an attribute is what the intellect perceives concerning a substance, as constituting its essence (by EId4); so (by EId3) it must be conceived through itself, q.e.d. ${ }^{6}$

Our question must be: does everything need to be conceived either through another or through itself in order for this demonstration to work? Clearly, the answer is no. Spinoza here is only making a claim about attributes of substances, which are conceived through themselves by definition. If there are other beings which are inconceivable, they are not substances and hence not in the scope of the claim of EIp10. Thus, this solution is a non-starter, since it does not identify a real gap in the argument that the unused axiom could fill.

Before moving to my positive proposal, it will be helpful to consider two other responses to the puzzle, which seek to dispel it without claiming that any of the particular proofs in the text has a gap. First, one might think that there are various places that Spinoza could have appealed to it instead of another axiom, but did not bother to mention it. For example, according to Bledin, Gartenberg, and Melamed, "Ethica more logico demonstrata", where Spinoza appeals to EIa1 in, for example, EIp4 and EIp6c, he could have run the proof just as well by replacing a1 with a2. This has the advantage of solving the puzzle without faulting any proofs in the Ethics as we have it. There are two

\footnotetext{
${ }^{5} \mathrm{EIa} 2$ is linked to Spinoza's rationalism and commitment to the principle of sufficient reason by Della Rocca, Spinoza; Garrett, Nature and Necessity (55); Lin, "Principle"; Lin, "Metaphysical Rationalism"; Melamed, "Spinoza on Inherence". For a skeptical take, see Schneider, "Spinoza's PSR". EIp4 is the most important premise in Spinoza's argument for monism beginning in EIp5 and culminating in EIp15.

6 Unumquodque unius substantiae attributum per se concipi debet. Demonstratio. Attributum enim est id, quod intellectus de substantia percipit tanquam ejus essentiam constituens (per defin. 4.); adeoque (per defin. 3.) per se concipi debet. Q. e. d.
} 
disadvantages to the approach. First, EIa2 still does not really need to be in the text. That everything in the world is conceivable seems to be a strong and interesting view, but on this interpretation, there is no claim in Spinoza that relies on it being true. So from the point of view of the geometrical method, Spinoza is still making a mistake by including it in his list. But on a more textual level, it would be surprising if Spinoza did not mention the possibility that is alluded to by this interpretation. In a number of propositions, he specifically mentions more than one way of proving a proposition but he does not do it in the relevant passages as Bledin, Gartenberg, and Melamed's interpretation would predict. One particularly striking example is EIp6c, which Spinoza gives multiple arguments for, none of which cite a2. So while this approach gives some work for a2 to do, it is not very much work and it is also not work that Spinoza gives any indication of it doing. The interpretation offered below improves on Bledin, Gartenberg, and Melamed's on both of these scores.

A second possible solution, inspired by Della Rocca's work, although not explicitly endorsed by him, would posit EIa2 as a background assumption guiding the operation of the entire system without being needed in any of the proofs. ${ }^{7}$ The idea is that, the intelligibility of the world is somehow built into the Spinozan framework, but is not an explicit proposition that is used in one or another proof. Like Bledin, Gartenberg, and Melamed, this can help us understand the significance of the axiom without placing it in a specific part of the text. But this interpretation nevertheless has the disadvantage of making this one axiom completely different in its operation from every other axiom (and definition) in the Ethics. Such an exception surely could have been noted, but was not. Indeed, the very fact that this axiom lies directly between two that are appealed to so explicitly and prominently in the first book of the Ethics (a1 is first mentioned in EIp4d, a3 in p27d) would make a reader expect that it should appear at least once in a proof.

Considering this solution, however, helps us to see a major desideratum of a good interpretation. What we want, if possible, is a way of integrating this axiom in a way that makes it not too unlike the other axioms and definitions, which have specific places in specific arguments for specific conclusions. This seems to me to be generally desirable, both based on considerations internal to Spinoza's text and due to the genre of geometrical text that the Ethics is imitating. Axioms in geometrical texts, both ancient and modern, are there to be used in proofs.

It is surprising that there has not been greater interest in solving this problem in the Anglophone literature, since this axiom contains one of Spinoza's clearest statements of the Principle of Sufficient Reason (PSR). In the work of Della Rocca, Garrett, Lin, and Melamed, EIa2 is frequently mentioned as a principle that Spinoza could appeal to to defend various theses. These authors, however, do not give sufficient attention to the fact that, as the text stands, none of the amazing propositions of the Ethics explicitly depend in any way shape or form on this axiom.

In what follows, I suggest that if we follow the trail of the early letters to Henry Oldenburg, we find Spinoza explicitly appealing to EIa2 and this appeal can lead us to a place in the Ethics where

\footnotetext{
7 An alternative reading of Della Rocca would have it that EIa2 is appealed to implicitly in a number of proofs. This alternative is not really distinct from the sort of solution that I myself (or Proietti/Mignini) will go on to suggest. This is why I say that the solution canvased above is "inspired" by Della Rocca.
} 
we need the axiom. ${ }^{8}$ The claim here is not that this is the only place where Spinoza should have also appealed to EIa2, but merely that here we have evidence that Spinoza intended to appeal to it. ${ }^{9}$ In the Appendix to the second letter, which is unfortunately lost, Spinoza aimed to show in a geometrical manner the following propositions:

[P1] That two substances cannot exist in nature unless they differ in their whole essence;

[P2] That a substance cannot be produced, but that it is of its essence to exist;

[P3] That every substance must be infinite, or supremely perfect in its kind. (Ep 2, IV/8/7$10)^{10}$

In the main text of the letter, Spinoza gives us two of the definitions he used:

[D1] God, whom I define as a Being consisting of infinite attributes, each of which is infinite, or supremely perfect in its kind. [...]

[D2] By attribute I understand whatever is conceived through itself and in itself, so that its concept does not involve the concept of another thing. (Ep 2, IV/7/23-28) ${ }^{11}$

We can tentatively reconstruct, based on Oldenburg's reply and Spinoza's reply to Oldenburg, some of what must have been in the Appendix. In the third letter, Oldenburg objects:

Third, do you regard the axioms you communicated to me as indemonstrable Principles, known by the light of Nature and requiring no proof? Perhaps the first is of that kind, but I do not see how the other three can be so regarded. The second supposes that [A2] nothing exists in Nature except Substances and Accidents, but many maintain that time and place are neither. I am so far from conceiving clearly your third axiom-[A3] Things which have different attributes have nothing in common with one another - that the whole universe of Things seems rather to prove its contrary. For all Things known to us both differ from one another in some respects and agree in others. Finally, the fourth axiom-[A4] If things have nothing in common with one another, one cannot be the cause of the other-is not so evident to my dull intellect that it does not need more light shed on it. Surely God has nothing formally in common with created things, yet nearly all of us regard him as their cause. (Ep 3, IV/10/29-11/14, my numbering of the axioms)

\footnotetext{
${ }^{8}$ On the letters, see Newlands, Reconceiving Spinoza (71 ff). The Appendix to the second letter is reconstructed by Battisti, "La dimostrazione dell'esistenza" and Hubelling, "The Development". On the place of the letters in Spinoza's development of geometric method, see Melamed, "The Earliest Draft".

${ }^{9}$ I suspect, although I do not have the textual evidence to secure it, that usually when Spinoza refers to the claim that everything in nature is either a substance or accident, he is implicitly appealing to a2, for reasons that will become clear below.

${ }^{10}$ Primo, quod in rerum natura non possunt existere duae substantiae, quin tota essentia differant. Secundo, substantiam non posse produci; sed quod sit de ipsius essentia existere. Tertio, quod omnis substantia debeat esse infinita, sive summe perfecta in suo genere[...]

${ }^{11}$ De Deo itaque incipiam breviter dicere; quem definio esse Ens, constans infinitis attributis, quorum unumquodque est infinitum, sive summè perfectum in suo genere. [...] Ubi notandum, me per attributum intelligere omne id, quod concipitur per se, \& in se; adeo ut ipsius conceptus non involvat conceptum alterius rei.
} 
The general tenor of Oldenburg's worry is clear enough. Spinoza's axioms cannot be too controversial if he is going to prove things with them. Many views, not just of normal people, but reflective philosophers, are inconsistent with those axioms. Spinoza replies, in a somewhat surprising manner, by proving these four propositions:

Your third objection against the things I proposed is that the Axioms ought not to be counted as common Notions. I have no quarrel with that. But you also doubt their truth; indeed you seem to want to show that their contrary is more likely. So please attend to the definitions I gave of Substance and of Accident, from which all these [axioms] are derived. For by Substance I understand what is conceived through itself and in itself, i.e., that whose concept does not involve the concept of another thing; but by modification, or Accident, what is in another and is conceived through what it is in. From this it is clear that:

[A1] Substance is by nature prior to its Accidents, for without it, they can neither be nor be conceived.

[A2] Except for Substances and Accidents, nothing exists in reality, or outside the intellect, for whatever there is, is conceived either through itself or through another, and its concept either does or does not involve the concept of another thing, [Nam quicquid datur, vel per se, vel per aliud concipitur, \& ipsius conceptus vel involvit conceptum alterius rei, vel non involvit.]

[A3] Things which have different attributes have nothing in common with one another, for I have explained that an attribute is that whose concept does not involve the concept of another thing.

[A4] If two things have nothing in common with one another, one cannot be the cause of the other, for since there would be nothing in the effect which it had in common with the cause, whatever the effect had, it would have from nothing. (Ep 4, IV/13/26-14/11)

I have retained Curley's formatting, but it is relatively clear from the parallels between A1, A2, A3, and A4 that the bolded section is meant to justify the inference from the definitions of substance and accident to A2 alone. This bolded section (which I will call A2') is the key, for it is logically equivalent to EIa2. ${ }^{12}$ At the risk of pedantry, I will give a quick argument for this. Suppose A2' and $x$ cannot be conceived through another. Since everything is conceived through itself or another, it must be conceived through itself. Thus A2' implies EIa2. For the other direction, suppose EIa2. Now suppose not A2' for reductio. Then there is an $x$ that is neither conceived through itself or through another. But by EIa2, if $x$ is not conceived through another, $x$ is conceived through itself. Contradiction.

I assume in this argument that EIa2 should be read as "if $x$ isn't conceived through itself, $x$ is conceived through another", but there is another option for understanding the axiom that is occasionally aired in the literature, for instance, in Schneider (2014). On this weaker reading, EIa2

12 Pace Newlands, Reconceiving Spinoza (72), who claims that it is “an early version of” EIa1. 
says "if $x$ is conceived, if $x$ isn't conceived through itself, $x$ is conceived through another." If we take this reading, EIa2 is obviously much weaker than A2. The argument in favor of this reading is that it better parallels EIa1: omnia quae sunt, vel in se vel in alio sunt. Just as there is a restriction to the things which are in the a1, so too in a 2 there should be a parallel restriction, which would be to those things which are conceived. But we should not be persuaded by this argument. The two axioms are evidently not linguistically parallel and so we should not try to insert a parallel restriction. On the one hand, a1 has an explicit quantifier, which is not present in a2. Moreover, a1 has a restriction marked by "quae" followed by a (presumably exclusive) disjunction, while there is clearly no such disjunction in a2. Furthermore, there is already a restriction mentioned in a2 in a relative clause: that $x$ cannot be conceived thought another. There is simply no grammatical space for another restriction unless we are also meant to supply a second relative clause. Finally, if we build in the proposed restriction, the axiom approaches triviality: everything that is conceived is either conceived through itself or something else-who would have thought otherwise? For these reasons, it is preferable to go with the traditional reading of a 2 and read it as equivalent to A2.

So we have identified the earliest occurrence in Spinoza of the mysterious axiom and see it is used to prove something. One does not have to look far to see where this point comes into play, for all of A1-4 have parallels as propositions or lemmata to propositions in the Ethics. I bold the linguistic parallels in the Latin so that we can see just how closely these are related.

Appendix Ethics

A1[= Ep 4, IV/14/1]: Substance is by nature EIp1: A substance is prior in nature to its prior to its Accidents. affections.

Substantia sit prior natura suis Substantia prior est natura suis Accidentibus. affectionibus.

$\mathrm{A} 2[=\mathrm{Ep} \mathrm{4,} \mathrm{IV/14/2-4]:} \mathrm{Except} \mathrm{for} \mathrm{EIp4d:} \mathrm{Whatever} \mathrm{is,} \mathrm{is} \mathrm{either} \mathrm{in} \mathrm{itself} \mathrm{or} \mathrm{in}$ Substances and Accidents, nothing exists in another (by EIal), i.e. (by EId3 and EId5), reality, or outside the intellect. outside the intellect there is nothing except Praeter Substantias, \& Accidentia nihil substances and their affections.

detur realiter, sive extra intellectum. Omnia, quae sunt, vel in se, vel in alio sunt (per axiom. 1.), hoc est (per defin. 3. et 5.), extra intellectum nihil datur praeter substantias earumque affectiones.

A3[= Ep 4, IV/14/6-7]: Things which have EIp2: Two substances having different different attributes have nothing in common attributes have nothing in common with one with one another. another.

Res, quae diversa habent attributa, nihil Duae substantiae, diversa attributa habent inter se commune. habentes, nihil inter se commune habent. 
A4[= Ep 4, IV/14/9-10]: If two things have EIp3: If things have nothing in common with nothing in common with one another, one one another, one of them cannot be the cause cannot be the cause of the other. of the other.

\section{Rerum, quae nihil commune habent inter Quae res nihil commune inter se habent, se, una alterius causa esse non potest. earum una alterius causa esse non potest.}

We see a general pattern: Spinoza realized here that the claims he originally presented as axioms in the Appendix, like Oldenburg said, are all in need of some justification. This is what he meant by saying that they are not "common notions". Moreover, he primarily appeals in these places to exactly what he told Oldenburg to attend to: the definitions of Substance and Accident (EId3 and EId5). These are the only assumptions referenced in EIp1-2. In the relevant part of the demonstration of EIp4d, he only appeals to d3, d5, and a1.$^{13}$ So, modulo EIp3, Spinoza has made good on his claim that the propositions follow from the definitions of substance and accident/affection. ${ }^{14}$

For our purposes, of course, it is the parallel to A2 that matters most. Here it seems that Spinoza has replaced the appeal to A2'/EIa2 with an appeal to EIa1 (and still appealing to the same definitions). But inspection of the reasoning suggests that what Spinoza directly cites is not in fact sufficient to prove what he wants to prove. Recall that substance and mode were each defined by a pair of properties:

EId3: By substance I understand what is in itself and is conceived through itself, i.e., that whose concept does not require the concept of another thing, from which it must be formed.

Per substantiam intelligo id, quod in se est et per se concipitur; hoc est id, cujus conceptus non indiget conceptu alterius rei, a quo formari debeat.

EId5: By mode I understand the affections of a substance, or that which is in another through which it is also conceived.

Per modum intelligo substantiae affectiones, sive id, quod in alio est, per quod etiam concipitur.

\footnotetext{
13 While it does not have great bearing on the argument that I am making here, it is important to note several differences in both terminology and argument in these otherwise parallel passages. In the Appendix, Spinoza prefers to contrast substance with its accidents, while in the Ethics, he contrasts it with affections. There may be significance in this shift, but it may also be simple varatio. However, a major difference between A3 and EIp2 is that the latter only applies to substances, whereas the former applies to "things" generally. Finally EIp3 appeals to two axioms (EIa4 and EIa5) not mentioned in the Appendix, which gives a very different demonstration of this proposition.

14 The case of EIp3/A3 is peculiar. In the Ethics, Spinoza appeals to EIa4 and a5, but even in the Appendix, it is clear that the justification for A3 has very little to do with the definitions.
} 
If Spinoza shows that everything is in something else or itself, that does not suffice to show that everything is either a substance or accident, since there could be (say) something inconceivable which is in itself or something inconceivable which is in something else. $\forall x((F x \wedge G x) \vee$ $\left.\left(F^{\prime} x \wedge G^{\prime} x\right)\right)$ simply does not follow from $\forall x\left(F x \vee F^{\prime} x\right)$. Adding EIa2 rules out this possibility and, since this was a principle that Spinoza himself thought was needed when proving this very proposition elsewhere, the absence of the reference here is not due to a larger failing in his reasoning.

There is, nevertheless, a lingering gap in the argument. Why couldn't something be in itself but conceived through another $?^{15}$ This would be consistent with both EIa1 and EIa2, but not with EIp4d. I suggest that Spinoza must here be operating with a relatively weak background assumption: if $x$ is conceived through $y$ and $x$ is in $z y=q{ }^{16}$ This is already in a way built into EId 3 and 5 , as the latter specifically assumes that what the mode is in is the very thing through which it is conceived. Once we have this assumption, then the claim in EIp4d that everything is either a substance or an accident does indeed follow from EIa1 and EIa2. ${ }^{17}$

An alternative solution would be simply to claim, as some have, that there is no difference in Spinoza between causation and inherence. ${ }^{18}$ If that were so, we could dispense with EIa2 entirely and have the claim that everything is a substance or accident follow merely from EIa1. It is not my place here to wade into the deep debate on inherence and conception in general in Spinoza. ${ }^{19}$ This is because I can stay neutral on the question of whether they end up coming to the same thing. What I want to resist is that Spinoza simply assumes at the outset of the Ethics that they are the same. I see no reason to believe this and it is difficult to square with the fact that they are apparently distinguished, for example, in the conjunctive definitions of substance and accident and the fact that EIa1 and EIa2 would otherwise collapse. The correspondence with Oldenburg shows that Spinoza is attentive to what a reader is willing to accept as an axiom and what they need to have demonstrated. It seems to me highly unlikely that he would set up the text of the Ethics in such a way as to generate the expectation in the reader that there are two relations, being in and being conceived through, but then throughout all of his argumentation act as if they were the same.

\footnotetext{
15 A problem already noted by Leibniz in his notes on the Ethics (Gerhardt, Die philosophischen Schriften, 139).

${ }^{16}$ I say "relatively weak" because this assumption itself has some rather counterintuitive consequences when paired with Spinoza's views about causation (Melamed, "Spinoza on Inherence"), but it is weaker than other candidate assumptions to save the argument, such as the one discussed in the next paragraph, which says that $x$ is conceived through $y$ if and only if $x$ is in $y$.

${ }^{17}$ In this way, it might be thought that a1 and a 2 underpin $\mathrm{d} 3$ and $\mathrm{d} 5$. If this is the case, why doesn't Spinoza himself directly connect them, as he so explicitly did in the letter to Oldenburg? There, recall, he did not separately mention these axioms, but simply used them as "inference tickets" when applying his definitions of substance and accident. No such connection is apparent in the Ethics. However, it is reasonable to think he still has this in mind, since a1 is usually mentioned alongside the definitions of substance and/or mode (e.g., EIp4, p6, p15, p28; exceptions are p11d3, p14c2). The exceptions, however, show that by the time he wrote the Ethics, Spinoza was also interested in implications of these principles that do not immediately require $\mathrm{d} 3$ and $\mathrm{d} 5$. This suggests that the definitions and the axioms can, to a certain extent, each stand on their own.

18 Most notably, perhaps, Della Rocca, Spinoza.

19 On this, see for example Della Rocca, Spinoza; Garrett, Nature and Necessity; Melamed, "Spinoza on Inherence"; Morrison, "Conception and Causation"; Newlands, Reconceiving Spinoza.
} 
With this in hand, we can now see an important role for our missing axiom. EIp4 is undoubtedly a linchpin of Spinoza's system and we have shown not only that the missing axiom was conceived of by Spinoza to be part of its justification, but that Spinoza was right to include it.

I will conclude by showing how this discovery sheds new light on another of Spinoza's statements of the PSR in the second proof of EIp11d:

For each thing there must be assigned a cause, or reason, as much for its existence as for its nonexistence.

Cuiuscumque rei assignari debet causa seu ratio, tam cur existit, quam cur non existit.

How should Spinoza justify this claim? According to Don Garrett, it is not itself directly justified:

It should be emphasized again, however, that Spinoza's own later expressions of the PSR or its corollaries-for example, the principle in the second proof in $1 \mathrm{p} 11 \mathrm{~d}$ that there must be a cause for the existence or nonexistence of each thing-do not actually cite any axiomatic basis for it. (Garrett, Nature and Necessity, 56)

But let us follow the trail back from what is cited in EIp11d2: namely p7 [it is of the nature of substance to exist]. This proposition depends on EIp6c, EIp6c depends on EIp6 and a1/d3/d5 (and probably also a2, since Spinoza cites these in EIp6c in support of the claim that everything is substance or mode, which is exactly what he needed a2 for in EIp4). EIp6 depends on EIp5 and EIp5 on EIp4, which is where I claimed a2 should have been used. Thus this investigation has revealed that Garrett's “axiomatic basis” is built already into EIp7 and thus into EIp11d2.

Moreover, it makes sense that a2 would be in the background of E1p11d2, since $\mathrm{d} 3$ and $\mathrm{d} 5$ require substance and modes respectively to be explained/caused, because inherence suffices for causation. ${ }^{20}$ Thus, substances are caused by themselves, while modes by what they inhere in. Since he uses a1/a2/d3/d5 in EIp4d to show that there is nothing besides substance and modes, these axioms and definitions together suffice for the claim that all things that exist have a cause for their existence, which is the first half of the EIp11d2 statement of the PSR. For the notorious negative half, that things that don't exist also need a cause for their non-existence, this claim also seems to help, although the reasoning is not as direct. First, assume that all possible things are either substances or modes. Then we have the following situation: if the possible thing is a substance, then it exists from its own nature. Thus any non-existent thing must be a mode. Since an underlying substance causes the modes that do exist to exist, it stands to reason that a substance would also cause the nonexisting modes not to exist. Otherwise, the absence of the mode (which is presumably also some "thing" in the broad sense of "something demanding a causal explanation") would not have a cause.

\footnotetext{
20 Although Spinoza is not especially forthcoming about the issue, scholars tend to agree he is committed to the principle that inherence implies causation (see, e.g., EIp16, which is explicit about the particular case of God). Scholars are divided, however, about the converse principle that causation implies inherence, and I am here taking no stand on this issue. For discussion, see the works cited in note 19 above.
} 
If the ontology extended beyond substances and modes (to include, for example, time and place, as Henry Oldenburg suggested above), there may be entities that need not be caused. In this case, it would be difficult to see why, for those things, if they didn't exist, there would need to be a cause for them. In conclusion, we can see why the lemma that everything is a substance or mode, substantiated by $\mathrm{d} 3 / \mathrm{d} 5 / \mathrm{a} 1$ and crucially a2, can support what is one of the seemingly strongest statements of the PSR in Spinoza.

\section{Acknowledgements}

I am grateful for the generous comments from Alexander Douglas and two anonymous referees. Special thanks to Kristin Primus for her invaluable advise during many discussions about these issues.

\section{Bibliography}

Battisti, Giuseppa Saccaro del Buffa. "La dimostrazione dell'esistenza di Dio dall'abbozzo del 1661 e dalla Korte Verhandeling al De Deo". In Dio, l'uomo, la libertà: Studi sul Breve Tratatto di Spinoza, edited by Filippo Mignini, 95-118. L’Aquila: Japadre, 1990.

Bledin, Justin, Zachary Gartenberg, and Melamed, Yitzhak. "Ethica more logico demonstrata." Manuscript.

Curley, Edwin. The Collected Works of Spinoza: Volume I. Princeton: Princeton University Press, 1985.

Della Rocca, Michael. Spinoza. New York: Routledge, 2008.

Garrett, Don. Nature and Necessity in Spinoza's Philosophy. Oxford: Oxford University Press, 2019.

Gebhardt, Carl. Spinoza Opera. Heidelberg: Carl Winters, 1925.

Gerhardt, Karl Immanuel. Die philosophischen Schriften von Gottfried Wilhelm Leibniz: Erster Band. Berlin: Weidman, 1875.

Hubbeling, Hubertus G. "The Development of Spinoza's Axiomatic (Geometric) Method". Revue Internationale de philosophie 31, no. 119/120 (1977): 53-68.

Kokomoor, F.W. “The Distinctive Features of Seventeenth Century Geometry”. Isis 13, no. 2 (1928): 367-415.

Lamy, Bernard. Les Éléments de Géométrie ou de la Mesure du Corps. Grenoble, 1685.

Lin, Martin. "The Principle of Sufficient Reason in Spinoza". In The Oxford Handbook of Spinoza, edited by Michael Della Rocca, 133-154. Oxford: Oxford University Press, 2017.

Lin, Martin. "Metaphysical Rationalism". In Spinoza in Twenty-First-Century French and American Philosophy, edited by Charles Ramond and Jack Stetter, 121-143. London: Bloomsbury, 2019.

Melamed, Yitzhak Y. "Spinoza on Inherence, Causation, and Conception". Journal of the History of Philosophy 50, no. 3 (2012): 365-386. doi:10.1353/hph.2012.0048.

Melamed, Yitzhak Y. "The Earliest Draft of Spinoza's Ethics". In Spinoza in Twenty-First-Century French and American Philosophy, edited by Charles Ramond and Jack Stetter, 93-112. London: Bloomsbury, 2019. 
Mignini, Filippo. Spinoza, Opere. Milano: Mondadori, 2007.

Morrison, John. "The Relation between Conception and Causation in Spinoza's Metaphysics". Philosophers' Imprint 13, no. 3 (2013): 1-17.

Mueller, Ian. "Euclid's Elements and the Axiomatic Method". The British Journal for the Philosophy of Science 20, no. 4 (1969): 289-309.

Mueller, Ian. Philosophy of Mathematics and Deductive Structure in Euclid's Elements. Cambridge: MIT Press, 1981.

Mueller, Ian. "On the Notion of a Mathematical Starting Point in Plato, Aristotle, and Euclid". In Science and Philosophy in Classical Greece, edited by A.C. Bowen, 59-97. New York: Garland, 1991.

Netz, Reviel. The Shaping of Deduction: A Study in Cognitive History. Cambridge: Cambridge University Press, 1999.

Newlands, Samuel. Reconceiving Spinoza. Oxford: Oxford University Press, 2018.

Proietti, Omero. "Sul problema di un assioma inutile in Spinoza". Rivista di Filosofia Neo-Scolastica 75, no. 2 (1983): 223-242.

Schneider, Daniel. "Spinoza's PSR as a Principle of Clear and Distinct Representation". Pacific Philosophical Quarterly 95, no. 1 (2014): 109-129. doi:10.1111/papq.12019. 